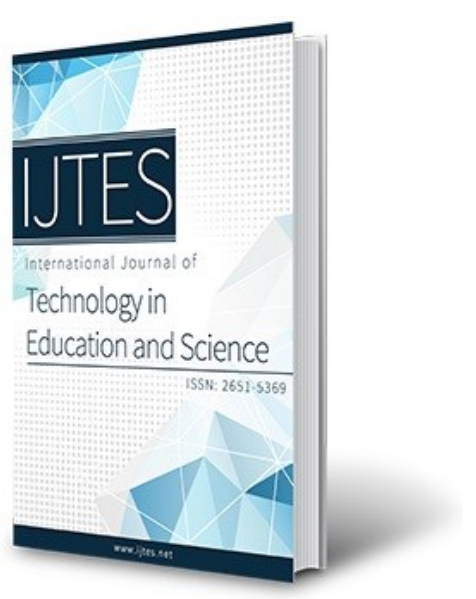

\title{
Cyberbullying/Cyber-Victimization \\ Status, Cyberbullying Awareness, and Combat Strategies of Administrators and Teachers of Pre-School Education Institutions
}

\author{
Nilgun Tosun \\ Trakya University, Turkey \\ Halenur Akcay \\ Trakya University, Turkey
}

$\underline{\text { www.ijtes.net }}$

\section{To cite this article:}

Tosun, N., \& Akcay, H. (2022). Cyberbullying/cyber-victimization status, cyberbullying awareness, and combat strategies of administrators and teachers of pre-school education institutions. International Journal of Technology in Education and Science (IJTES), 6(1), 44-73. https://doi.org/10.46328/ijtes.336

\footnotetext{
The International Journal of Technology in Education and Science (IJTES) is a peer-reviewed scholarly online journal. This article may be used for research, teaching, and private study purposes. Authors alone are responsible for the contents of their articles. The journal owns the copyright of the articles. The publisher shall not be liable for any loss, actions, claims, proceedings, demand, or costs or damages whatsoever or howsoever caused arising directly or indirectly in connection with or arising out of the use of the research material. All authors are requested to disclose any actual or potential conflict of interest including any financial, personal or other relationships with other people or organizations regarding the submitted work.
} 


\title{
Cyberbullying/Cyber-Victimization Status, Cyberbullying Awareness, and Combat Strategies of Administrators and Teachers of Pre-School Education Institutions
}

\author{
Nilgun Tosun, Halenur Akcay
}

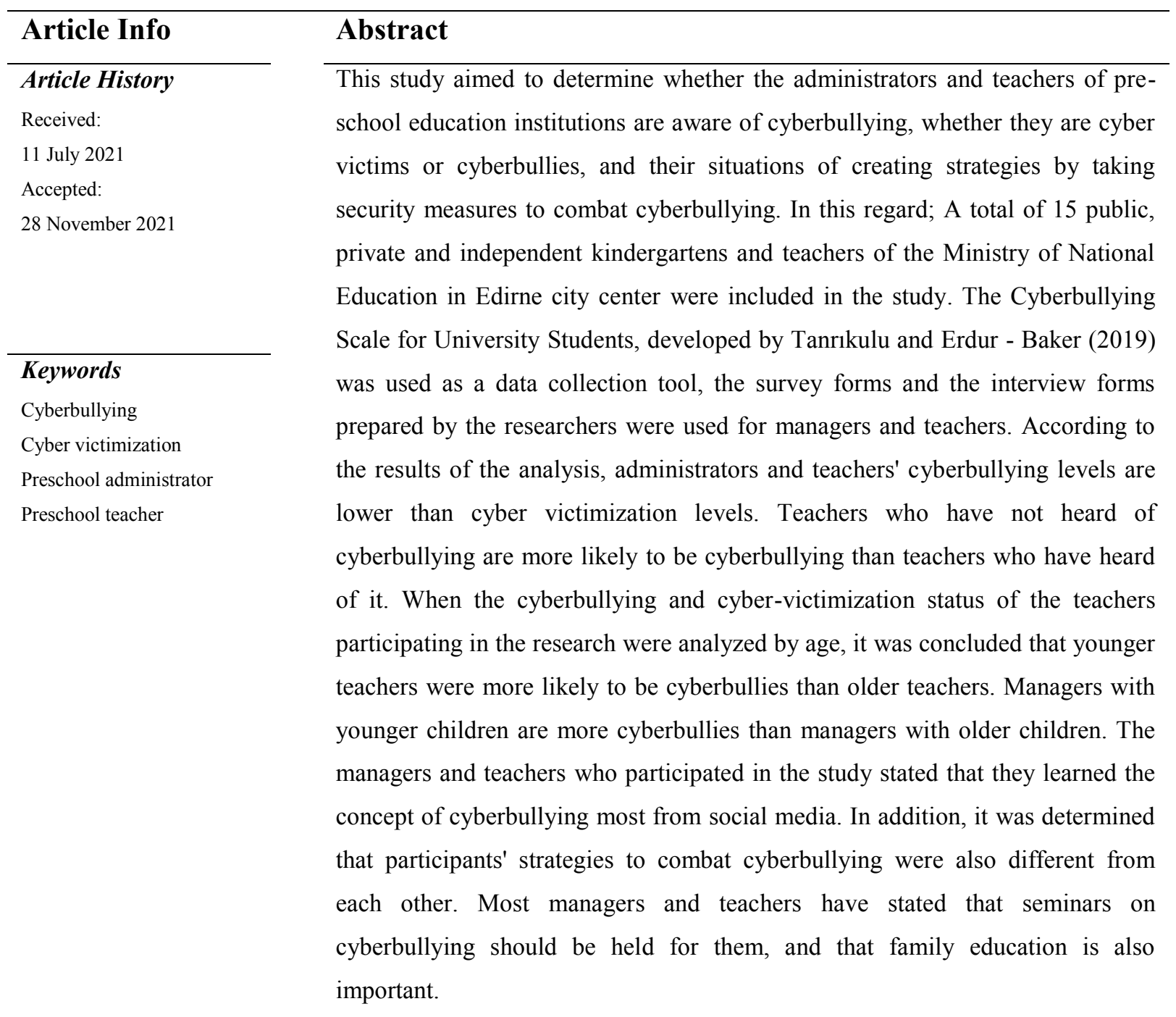

\section{Introduction}

The Internet is a crucial platform that facilitates every aspect of life, contributes to the individuals' socialization, and especially enables the acquisition and dissemination of information. Thanks to this technology, individuals socialize using tools such as social media, instant messaging applications, online games, and e-mails. Despite all these advantages, the internet also has factors that may negatively affect the social life and psychology of individuals. E-mails containing harmful content or viruses can be sent using Internet tools. Instant and defamation messages containing insults, threats, attacks or inappropriate content are also common. In addition, 
inappropriate videos and photos posted on social networking sites may harm individuals. O'Keeffe and ClarkePearson (2011) point out to the fact that negative behaviors that disseminate false information, embarrassing or hostile interaction about others may also occur on the Internet.

The Internet and social networks have become an environment where individuals threaten, harass, intimidate, and gossip about other people (Dehue, 2013; Patchin and Hinduja, 2006). Taiwo (2015) on the other hand, emphasized that the internet and social networks also paved the way for the unwanted behavior of untrusted individuals with different identities who create multiple identities, lie about their gender, mask their identities, steal identity, and use pseudonyms. Such behaviors are the dark side of the internet and social networks, and are known as cyberbullying (Li, 2007; Tokunaga, 2010). Bullying, which is expressed by hitting, pushing, hurting physically or giving nicknames, mocking, and threating verbally in real life, is seen in different ways in the digital world. The concept of cyberbullying manifests itself with factors such as sending e-mail with a confidential identity, leaving a call from an unknown number, making calls, spreading defamatory and threatening texts, voices, and images; swearing, threaten and insulting on online platforms.

Nowadays, children can benefit from opportunities such as education, entertainment and communication through digital media. The fact that digital media is a part of daily life has caused these opportunities to emerge (Higgins, Xiao, and Katsipataki, 2012). This has increased the importance of protecting children from the risks they may encounter while using digital media (Hamer, Stamatakis, and Mistras, 2009; Livingstone, Mascheroni, and Staksrud, 2015). The fact that children are introduced to digital media at a very early age and that digital media offers online access opportunities means that they also encounter many risks. These risks include content risks such as violence, pornography and hate speech, contact risks such as insults, abuse, ideological brainwashing, and misuse of personal data, cyberbullying, gambling and cybercrime (Livingstone and Haddon, 2009).

Due to the use of smart phones, tablets, computers, virtual and augmented reality applications, and wearable technologies for educational purposes in schools, students have started to spend most of their time online. This has led to an increase in cyberbullying in schools. In studies conducted around the world (Doane, Kelley, Chiang, and Padilla, 2013; Hinduja and Patchin, 2008; PRC, 2017; Serin, 2012; Uygarer, 2019), it has been revealed that the cyberbullying in schools are increasing more and more each day. Therefore, according to Aksaray (2011); school staff should take an active role in cyberbullying and awareness should be created on this issue.

In future school management policies, Internet use should be explained to students correctly, more frequent studies should be done with students, professional help should be provided by gathering with the victim or bully, and the family should be included. According to some studies, especially adolescents do not share their exposure to violence over the internet with their parents. It has been observed that most of the victims did not tell anyone about what happened to them, and those who did told firstly to their friends and then to their parents or teachers. 
According to Taylan, Aydin and Topal (2017); when looking at the studies conducted in Turkey in recent years, it is observed that the cyberbullying rates vary between $7 \%$ and $28 \%$. The fact that the cyberbullying is becoming more frequent in Turkey indicates that studies on this matter should be also expanded. When the literature in Turkey is examined, it is observed that there is no research for teachers and administrators working in pre-school institutions on cyberbullying. This present study is considered important in this aspect.

The aim of this study is to determine whether the teachers and administrators working in pre-school education institutions in Edirne are cyber victims or cyberbullies, whether they are aware of cyberbullying and the strategies that they have developed to combat cyberbullying. In line with this general purpose, the study will investigate the following questions:

1. What is the status of the teachers and administrators participating in the study being cyberbullies and cyber victims?

2. Does the status of the teachers participating in the study being cyberbullies and cyber victims differ according to;

- Gender,

- Age,

- Having children,

- Average time of daily internet usage,

- Awareness of cyberbullying?

3. Does the status of the administrators participating in the study being cyberbullies and cyber victims differ according to;

- Gender,

- Age,

- Having children,

- Average time of daily internet usage,

- Awareness of cyberbullying?

4. Do the teachers and administrators participating in the study have awareness of cyberbullying?

5. What are the strategies of teachers and administrators participating in the research to combat cyberbullying?

\section{Method}

\section{Model of Research}

A mixed model was used as a research model in this study. The mixed research model covers collecting qualitative and quantitative data on the same primary phenomenon in a study, analyzing and interpreting data (Leech and Onwuegbuzie, 2007). The descriptive survey model among quantitative research methods and case study research among qualitative research methods were used. The findings obtained by the descriptive survey model in the study were supported by qualitative data obtained through interviews. 


\section{Participant Characteristics}

The study was carried out with 56 teachers and 25 administrators working in institutions with official, private and independent kindergartens and public nursery classes affiliated to the Ministry of National Education in the city center of Edirne. The convenience sampling method was used from the non-random sampling methods in determining schools. The main objective of the convenience sampling method is to prevent loss of time, money, and labor (Büyüköztürk, Çakmak, Akgün, Karadeniz, \& Demirel, 2017). The demographic information of the teachers participating in the research is given in Table 1.

Table 1. Demographic Information of Teachers

\begin{tabular}{|c|c|c|c|}
\hline \multicolumn{2}{|c|}{ Demographic Characteristics } & Frequency & Percentage \\
\hline \multirow{2}{*}{ Gender } & Female & 54 & 96.4 \\
\hline & Male & 2 & 3.6 \\
\hline \multirow{4}{*}{ Age } & $18-28$ & 23 & 41.1 \\
\hline & $29-39$ & 22 & 39.3 \\
\hline & $40-50$ & 9 & 16.1 \\
\hline & over 50 & 2 & 3.6 \\
\hline \multirow{2}{*}{ Graduation Status } & Bachelor's degree & 55 & 98.2 \\
\hline & Master & 1 & 1.8 \\
\hline \multirow{5}{*}{ Years of seniority } & $0-5$ years & 28 & 50 \\
\hline & $6-11$ years & 18 & 32.1 \\
\hline & $12-17$ years & 7 & 12.5 \\
\hline & 18-23 years & - & - \\
\hline & 24 and over & 3 & 5.4 \\
\hline \multirow{2}{*}{ Marital Status } & Married & 40 & 71.4 \\
\hline & Single & 16 & 28.6 \\
\hline \multirow{3}{*}{ Children } & Yes & 26 & 46.4 \\
\hline & No & 30 & 53.6 \\
\hline & Total & 56 & \\
\hline \multirow[t]{6}{*}{$\begin{array}{l}\text { School level of the } \\
\text { child }\end{array}$} & Preschool & 13 & 50 \\
\hline & Primary school & 6 & 23 \\
\hline & Secondary school & 2 & 8 \\
\hline & High school & 1 & 4 \\
\hline & University & 4 & 15 \\
\hline & Total & 26 & \\
\hline
\end{tabular}

The demographic information of the administrators participating in the research is presented in Table 2. 
Table 2. Demographic Information of Administrators

\begin{tabular}{|c|c|c|c|}
\hline & raphic Characteristics & Frequency & Percentage \\
\hline \multirow{2}{*}{ Gender } & Female & 14 & 56 \\
\hline & Male & 11 & 44 \\
\hline \multirow{4}{*}{ Age } & $18-28$ & 3 & 12 \\
\hline & $29-39$ & 5 & 20 \\
\hline & $40-50$ & 13 & 52 \\
\hline & over 50 & 4 & 16 \\
\hline \multirow{2}{*}{ Graduation Status } & Bachelor's degree & 21 & 84 \\
\hline & Master & 4 & 16 \\
\hline \multirow{5}{*}{ Years of seniority } & $0-5$ years & 10 & 40 \\
\hline & $6-11$ years & 6 & 24 \\
\hline & $12-17$ years & 4 & 16 \\
\hline & $18-23$ years & 3 & 12 \\
\hline & 24 and over & 2 & 8 \\
\hline \multirow{2}{*}{ Marital Status } & Married & 22 & 88 \\
\hline & Single & 3 & 12 \\
\hline \multirow{3}{*}{ Children } & Yes & 22 & 88 \\
\hline & No & 3 & 12 \\
\hline & Total & 25 & \\
\hline \multirow{6}{*}{ Years of seniority } & Preschool & 6 & 27 \\
\hline & Primary school & 2 & 9 \\
\hline & Secondary school & 4 & 18 \\
\hline & High school & 5 & 23 \\
\hline & University & 5 & 23 \\
\hline & Total & 22 & \\
\hline
\end{tabular}

\section{Data Collection Tools}

The Cyberbullying Scale for University Students, developed by Tanrikulu and Erdur Baker (2020), is one of the data collection tools used in research. It consists of a total of 22 items. The scale is rated in the type of 4-Likert. There are 11 items in the Cyberbully and 11 items in the Cyber Victim section of the scale, and the highest score that can be obtained from these sections is 33 and the lowest score is 0 . The high score indicates a high level of cyberbullying and cyber victimization. The internal consistency reliability coefficients of the scale are 34 and 60 for each section. In this study, the Cronbach Alpha value was found as 0.72 for cyberbullying section and 0.78 for the cyber victim section. The original scale was developed by working on university students. However, the scale was applied to adults in this research. Therefore, there was no need for invariance analysis for the scale because measurement invariance tests are a kind of covariance structure analysis and are designed to measure a certain structure in different groups (Jöreskog and Sörbom, 1999). 
Another data collection tool used in the research is the questionnaire forms developed by the researchers separately for teachers and administrators. During the development process of each questionnaire form, similar studies were examined by reviewing the relevant body of literature. After the questions were written, expert opinions were sought on the content validity of the questionnaires. For this purpose, 2 faculty members of Computer Education and Instructional Technology Department and 2 Information Technologies teachers were consulted for their opinions and questions that were not suitable for the purpose were removed in line with their opinions. For the linguistic validity of the questionnaires, 1 faculty member of the Turkish Language Teaching Department and 1 Turkish teacher were consulted for their opinions and the questionnaires were finalized. In each of the questionnaire forms developed for teachers and administrators, there are 19 questions, one of which is open-ended question and the others are multiple-choice question.

Interview forms developed by the researchers for teachers and administrators were also used in the research. For the content and linguistic validity, the opinions of the experts were taken and the forms were finalized. There are 4 semi-structured questions in the interview form applied to teachers and administrators.

\section{Data Collection}

During the data collection phase, an appointment was made with the administrator of each institution and a meeting was held at first. In the meeting, the administrators were informed about the thesis subject, its purpose, data collection tools, and itinerary. The data collection process was started by issuing the questionnaire and scale forms to the administrators. The questionnaire and scale forms were collected from the administrators one week later. In the second stage, we visited schools to distribute teacher questionnaire and scale forms on the day and time determined by the administrators. During these visits, the teachers were informed about the subject and purpose of the thesis, as well as the questionnaire and scale forms which they were asked to fill. The questionnaire and scale forms were collected from the teachers one week later. Interviews with the administrators were conducted on the day the administrator questionnaire and scale forms were received from them. The interviews were conducted on a voluntary basis. For this reason, interviews were held with 7 principals and 6 deputy principals. Principals who did not want to have an interview stated that they did not have time and assigned the deputy principals. Teacher interviews were conducted on a voluntary basis, as were the administrator interviews. For this reason, 25 teachers answered to the interview questions. Some of the other teachers stated that they did not have time, while some did not want to have an interview. Interviews with all administrators, assistant administrators and teachers were conducted face-to-face by an appointment.

\section{Data Analysis}

The normality values of the existing variables of cyberbullying and cyber victimization were analyzed in the research. The data of the teachers were analyzed with the Kolmogorov Smirnov test and the data of the administrators were analyzed with the Shapiro Wilk test since the sample size was 25 . The obtained results are given in Table 3. 
Table 3. Normality Analysis Results of Cyberbullying / Cyber-Victimization Variables

\begin{tabular}{lccc}
\hline & Statistics & Df & Sig \\
\hline Teacher & 0.516 & 56 & 0.00 \\
Administrator & 0.203 & 25 & 0.00 \\
Teacher & 0.395 & 56 & 0.00 \\
Administrator & 0.316 & 25 & 0.00 \\
\hline
\end{tabular}

According to the results of the normality test in Table 3, it is seen that none of the cyberbully and cyber victim variables of teachers and administrators can provide the assumption of normality $(p<0.05)$. Within the scope of the research, Frequency analysis was used for the information obtained through questionnaires, difference tests (Mann-Whitney U and Kruskal Wallis) were used based on the data obtained from the scale, and content analysis was used for the data obtained from the interview forms. SPSS 24 package program was used for all analyses.

\section{Results}

In this study conducted with 56 teachers and 25 administrators, the descriptive statistics of the participants' cyberbully and cyber victim scores were examined. The results obtained are presented in Table 4.

Table 4. Descriptive Statistics of Teachers' and Administrators' Cyberbully and Cyber Victim Scores

\begin{tabular}{llcccccccccc}
\hline & $\mathrm{N}$ & $\bar{X}$ & $X_{\text {ort }}$ & $X_{\text {tep }}$ & S.S. & $i h_{\bar{X}}$ & Skewness & Kurtosis & Min & Max \\
\hline Teacher & Cyberbully & 56 & 0.30 & 0 & 0 & 0.970 & 0.13 & 3.549 & 12.961 & 0 & 5 \\
& Cybervictim & 56 & 1.26 & 0 & 0 & 2.43 & 0.32 & 1.952 & 2.809 & 0 & 9 \\
\multirow{3}{*}{ Administrator } & Cyberbully & 25 & 0.12 & 0 & 0 & 0.6 & 0.12 & 5 & 25 & 0 & 3 \\
& Cybervictim & 25 & 1.6 & 0 & 0 & 5.6 & 1.12 & 3.43 & 11.01 & 0 & 23 \\
\hline
\end{tabular}

In Table 4, the descriptive values of 56 teachers are presented. Accordingly, teachers' average cyberbully score is 0.30 ; the median value is 0 and the mode value is 0 . The calculated standard deviation value is 0.970 . The teacher with the lowest "cyberbully" score has 0 points, and the teacher with the highest score has 5 points. A maximum of 33 and a minimum of 0 points can be scored from this dimension, which consists of 11 items. When the scores are examined, it can be concluded that the cyberbullying levels of the participating teachers are low. The table also includes descriptive statistics about the cyber victim dimension of teachers. When these values are examined, the arithmetic mean is 1.26; the median value is 0 and the mode value is 0 . The calculated standard deviation value is 2.43 . The teacher with the lowest "cyber victim" score among the participants has 0 point, and the teacher with the highest score has 9 points. When the scores are examined, it can be concluded that the cyber victim levels of the participating teachers are low. In this context, when the descriptive statistics of the two dimensions are compared; it can be stated that teachers' "cyberbully" levels are lower than "cyber victim" levels.

Table 4 also includes descriptive values of 25 administrators. Accordingly, administrators' average cyberbully 
score is 0.12 ; the median value is 0 and the mode value is 0 . The calculated standard deviation value is 0.6 . The administrator with the lowest "cyber victim" score among the participants has 0 point, and the administrator with the highest score has 3 points. When the scores are examined, it can be concluded that the cyberbullying levels of the participating administrators are low.

The table also includes descriptive statistics about the cyber victim dimension of administrators. When these values are examined, the arithmetic mean is 1.6; the median value is 0 and the mode value is 0 . The calculated standard deviation value is 5.6. The administrator with the lowest "cyber victim" score among the participants has 0 point, and the administrator with the highest score has 23 points. When the scores are examined, it can be concluded that the cyber victim levels of the participating administrators are low. In this context, when the descriptive statistics of the two dimensions are compared; it can be stated that administrators' "cyberbully" levels are lower than "cyber victim" levels.

It has also been examined whether there is a differentiation between teachers and administrators in cyberbullying and victimization. In Table 5, descriptive statistics of the cyberbully and cyber victim scores of the participants are given separately.

Table 5. Descriptive Statistics of Teachers' and Administrators' Differences in Being a Cyberbully and Victim

\begin{tabular}{lllll}
\hline & Participants & $\mathrm{N}$ & $\bar{X}$ & $\mathrm{SS}$ \\
\hline Cyberbully & Teacher & 56 & .30 & .971 \\
& Administrator & 25 & .12 & .600 \\
Cybervictim & Teacher & 56 & 1.27 & 2.431 \\
& Administrator & 25 & 1.60 & 5.605 \\
\hline
\end{tabular}

When Table 5 is examined, it is seen that teachers have higher cyberbullying mean scores than administrators. When the cyber victim mean scores are compared, it is concluded that the mean score of the administrators is higher than that of the teachers. Kruskal Wallis was applied to test the statistical significance of the difference between the means and the results are given in Table 6 .

Table 6. The Results of the Kruskal Wallis Test in terms of the Cyberbullying and Victimization of the Participants as Teachers and Managers

\begin{tabular}{lllcccc}
\hline & Participants & $\mathrm{N}$ & $\begin{array}{c}\text { Rank } \\
\text { Average }\end{array}$ & $\mathrm{X}^{2}$ & $\mathrm{Sd}$ & $\mathrm{p}$ \\
\hline Cyberbully & Teacher & 56 & 320.01 & 1.098 & 2 & .578 \\
& Administrator & 25 & 298.98 & & & \\
Cyber victim & Teacher & 56 & 343.46 & 5.563 & 2 & .062 \\
& Administrator & 25 & 274.20 & & & \\
\hline
\end{tabular}

According to Table 6, cyberbullying status does not differ statistically significantly in terms of the type of 
participant $\left(\mathrm{X}^{2}=1.098 ; \mathrm{sd}=2 ; \mathrm{p}>0.05\right)$. After examining the status of participants as cyber victims, no statistically significant difference was found again $\left(X^{2}=5.563 ; \mathrm{sd}=2 ; \mathrm{p}>0.05\right)$.

The Mann Whitney $U$ test results regarding whether teachers' cyberbullying and victimization differ significantly in terms of gender are given in Table 7.

Table 7. Mann Whitney U Test Results of Teachers' Cyberbullying and Victimization Status in terms of Gender

\begin{tabular}{llcccccc}
\hline & Gender & N & Rank Sum & $\begin{array}{c}\text { Rank } \\
\text { Average }\end{array}$ & U & Z & p \\
\hline \multirow{2}{*}{ Cyberbully } & Female & 54 & 1545.00 & 28.61 & 48 & -0.494 & 0.812 \\
& Male & 2 & 51.00 & 25.5 & & & \\
Cybervictim & Female & 54 & 1529.50 & 28.32 & 63.5 & 0.516 & 0.687 \\
& Male & 2 & 66.50 & 33.25 & & & \\
\hline
\end{tabular}

When Table 7 is examined, it is seen that in teachers being a cyberbully does not differ statistically significantly in terms of gender $(U=48 ; p>0.05)$. When cyber victimization scores are examined, it is seen that these scores do not differ statistically significantly in terms of gender $(U=63.5 ; p>0.05)$.

The cyberbullying and victimization of teachers were examined in terms of age variable. The results of the Kruskal-Wallis test are given in Table 8.

Table 8. Mann Whitney U Test Results of Teachers' Cyberbullying and Victimization Status in terms of Age

\begin{tabular}{llccccc}
\hline & Age & $\mathrm{N}$ & $\begin{array}{c}\text { Rank } \\
\text { Average }\end{array}$ & $\mathrm{X}^{2}$ & $\mathrm{Sd}$ & $\mathrm{p}$ \\
\hline Cyberbully & $18-28$ & 23 & 32.80 & 9.441 & 3 & .024 \\
& $29-39$ & 22 & 25.50 & & & \\
& $40-50$ & 9 & 25.50 & & & \\
Cybervictim & over 50 & 2 & 25.50 & & & \\
& $18-28$ & 23 & 34.11 & 8.951 & 3 & .030 \\
& $29-39$ & 22 & 26.89 & & & \\
& $40-50$ & 9 & 20.00 & & & \\
& over 50 & 2 & 20.00 & & & \\
\hline
\end{tabular}

According to Table 8, cyberbullying status of teachers differ statistically significantly in terms of age $\left(X^{2}=9.441 ; s d=3 ; p<0.05\right)$. As a result of the comparisons made with the Mann Whitney $U$ test, it can be concluded that the most basic difference is between teachers aged 18-28 and aged 40-50 (U =187; $<<0.05)$ and that young teachers are more bullies. Similarly, as a result of examining the cyber victimization in terms of age, a statistically significant difference was found $\left(X^{2}=8.951 ; \mathrm{sd}=3 ; \mathrm{p}<0.05\right)$. As a result of the comparisons made with the Mann Whitney U test, it can be concluded that the most basic difference is between teachers aged 1828 and aged $40-50(\mathrm{U}=54 ; \mathrm{p}<0.05)$ and that older teachers are more victims. 
The Mann Whitney $U$ test results regarding whether teachers' cyberbullying and victimization differ significantly in terms of having children are given in Table 9.

Table 9. Mann Whitney U Test Results of Teachers' Cyberbullying and Victimization Status in terms of Having Children

\begin{tabular}{lllrrrrr}
\hline & Children? & $\mathrm{N}$ & Rank Sum & $\begin{array}{c}\text { Rank } \\
\text { Average }\end{array}$ & $\mathrm{U}$ & $\mathrm{Z}$ & $\mathrm{p}$ \\
\hline Cyberbully & Yes & 26 & 663.00 & 25.00 & 299.000 & -2.431 & .015 \\
& No & 30 & 933.00 & 30.69 & & & \\
Cybervictim & Yes & 26 & 628.50 & 23.60 & 262.500 & -2.359 & .018 \\
& No & 30 & 967.50 & 31.95 & & & \\
\hline
\end{tabular}

When Table 9 is examined, it is seen that in teachers being a cyberbully differs statistically significantly in terms of having children $(U=299 ; p<0.05)$. It was concluded that those who do not have children have a higher cyberbullying mean score $(\mathrm{SO}=30.69)$ than those who have children $(\mathrm{SO}=25)$. When cyber victimization scores are examined, it is seen that these scores differ statistically significantly in terms of having children (U=262.5; $\mathrm{p}<0.05)$. Similarly, it was concluded that teachers who do not have children have a higher cyber victimization mean score $(\mathrm{SO}=31.95)$ than those who have children $(\mathrm{SO}=23.6)$.

The cyberbullying and victimization status of the teachers was examined in terms of the daily average internet usage duration variable. The results of the Kruskal-Wallis test are given in Table 10.

Table 10. Kruskal-Wallis Test Results of Teachers' Cyberbullying and Victimization in terms of Daily Average Internet Usage Duration

\begin{tabular}{llccccc}
\hline & $\begin{array}{l}\text { Daily Average Internet } \\
\text { Usage Duration }\end{array}$ & $\mathrm{N}$ & $\begin{array}{c}\text { Rank } \\
\text { Average }\end{array}$ & $\mathrm{X}^{2}$ & $\mathrm{Sd}$ & $\mathrm{p}$ \\
\hline Cyberbully & 0-2 hours & 38 & 26.21 & 9.034 & 2 & .011 \\
& 3-5 hours & 16 & 32.63 & & & \\
& 6-8 hours & 2 & 39.00 & & & .091 \\
Cybervictim & 0-2 hours & 38 & 25.84 & 4.790 & 2 & \\
& 3-5 hours & 16 & 33.88 & & & \\
& 6-8 hours & 2 & 36.00 & & & \\
\hline
\end{tabular}

According to Table 10, the cyberbullying status of the teachers differs statistically significantly in terms of daily average internet usage duration $\left(\mathrm{X}^{2}=9.034 ; \mathrm{sd}=2 ; \mathrm{p}<0.05\right)$. As a result of the comparisons made with the Mann Whitney $U$ test, it was concluded that the most basic difference is between teachers who use the internet for an average of 0-2 hours daily and those who use the internet for 3-5 hours $(U=235 ; \mathrm{p}<0.05)$. As a result of examining the cyber victimization of teachers in terms of daily average internet usage duration, there was no statistically significant difference $\left(X^{2}=4.790 ; \mathrm{sd}=2 ; \mathrm{p}>0.05\right)$. 
The Mann Whitney $U$ test results regarding whether teachers' cyberbullying and victimization differ significantly in terms of having heard of the concept of cyberbullying are given in Table 11.

Table 11. Mann Whitney U Test Results of Teachers' Cyberbullying and Victimization Status in terms of Cyberbullying Awareness

\begin{tabular}{llcccccc}
\hline & $\begin{array}{l}\text { The awareness } \\
\text { of cyberbullying }\end{array}$ & $\mathrm{N}$ & Rank Sum & $\begin{array}{c}\text { Rank } \\
\text { Average }\end{array}$ & $\mathrm{U}$ & $\mathrm{Z}$ & $\mathrm{p}$ \\
\hline \multirow{2}{*}{ Cyberbully } & Yes & 48 & 1308.50 & 27.26 & 132.500 & -2.596 & .009 \\
& No & 8 & 287.50 & 35.94 & & & \\
\multirow{5}{*}{ Cybervictim } & Yes & 48 & 1342.50 & 27.97 & 166.500 & -.734 & .463 \\
& No & 8 & 253.50 & 31.69 & & & \\
\hline
\end{tabular}

According to Table 11, It is seen that being a cyberbully has a statistically significant difference in terms of having heard the concept $(\mathrm{U}=132.5 ; \mathrm{p}<0.05)$. It was concluded that teachers who had not heard of the concept of cyberbullying $(\mathrm{SO}=35.94)$ were more bullies than those who had heard about it $(\mathrm{SO}=27.6)$. When teachers' scores of being cyber victims are examined, it is seen that these scores do not differ statistically significantly in terms of hearing the concept of cyberbullying $(U=166.5 ; p>0.05)$.

The Mann Whitney U test results regarding whether administrators' cyberbullying and victimization differ significantly in terms of gender are given in Table 12.

Table 12. Mann Whitney U Test Results of Administrators' Cyberbullying and Victimization Status in terms of Gender

\begin{tabular}{lllccccc}
\hline & Gender & $\mathrm{N}$ & Rank Sum & $\begin{array}{c}\text { Rank } \\
\text { Average }\end{array}$ & $\mathrm{U}$ & $\mathrm{Z}$ & $\mathrm{p}$ \\
\hline \multirow{2}{*}{ Cyberbully } & Female & 14 & 187.50 & 13.39 & 71.500 & -.886 & .375 \\
& Male & 11 & 137.50 & 12.50 & & & \\
& Female & 14 & 193.00 & 13.79 & 66.000 & -1.279 & .201 \\
& Male & 11 & 132.00 & 12.00 & & & \\
\hline
\end{tabular}

According to Table 12, it is seen that in administrators being a cyberbully does not differ statistically significantly in terms of gender $(U=71.5 ; p>0.05)$. When cyber victimization scores are examined, it is seen that these scores do not differ statistically significantly in terms of gender $(U=66 ; p>0.05)$.

The cyberbullying and victimization of administrators were examined in terms of age variable. The results of the Kruskal-Wallis test are given in Table 13. According to Table 13, cyberbullying status of administrators does not differ statistically significantly in terms of age $\left(X^{2}=4 ; s d=3 ; p>0.05\right)$. Similarly, as a result of examining the cyber victimization in terms of age, there was no statistically significant difference $\left(X^{2}=1.4 ; s d=3 ; p>0.05\right)$. 
Table 13. Mann Whitney U Test Results of Administrators' Cyberbullying and Victimization Status in terms of

\begin{tabular}{|c|c|c|c|c|c|c|}
\hline \multicolumn{7}{|c|}{ Age } \\
\hline & Age & $\mathrm{N}$ & Rank Average & $\mathrm{X}^{2}$ & $\mathrm{Sd}$ & $\mathrm{p}$ \\
\hline \multirow{3}{*}{ Cyberbully } & $18-28$ & 3 & 12.50 & 4.000 & 3 & .261 \\
\hline & $29-39$ & 5 & 15.00 & & & \\
\hline & $40-50$ & 13 & 12.50 & & & \\
\hline \multirow{5}{*}{ Cybervictim } & over 50 & 4 & 12.50 & & & \\
\hline & $18-28$ & 3 & 12.00 & 1.400 & 3 & .706 \\
\hline & $29-39$ & 5 & 14.40 & & & \\
\hline & $40-50$ & 13 & 13.00 & & & \\
\hline & over 50 & 4 & 12.00 & & & \\
\hline
\end{tabular}

The Mann Whitney U test results regarding whether administrators' cyberbullying and victimization differ significantly in terms of having children are given in Table 14.

Table 14. Mann Whitney U Test Results of Administrators' Cyberbullying and Victimization Status in terms of Having Children

\begin{tabular}{llcccccc}
\hline & Children ? & $\mathrm{N}$ & Rank Sum & Rank Average & $\mathrm{U}$ & $\mathrm{Z}$ & $\mathrm{p}$ \\
\hline Cyberbully & Yes & 22 & 287.50 & 13.07 & 31.500 & -.369 & .712 \\
& No & 3 & 37.50 & 12.50 & & & \\
Cybervictim & Yes & 22 & 289.00 & 13.14 & 30.000 & -.533 & .594 \\
& No & 3 & 36.00 & 12.00 & & & \\
\hline
\end{tabular}

When Table 14 is examined, it is seen that in administrators being a cyberbully does not differ statistically significantly in terms of having children $(U=31.5 ; p>0.05)$. When cyber victimization scores are examined, it is seen that these scores do not differ statistically significantly in terms of having children $(U=30 ; p>0.05)$.

The cyberbullying and victimization status of the administrators was examined in terms of the daily average internet usage duration variable. The results of the Kruskal-Wallis test are given in Table 15.

Table 15. Kruskal Wallis Test Results of Administrators' Cyberbullying and Victimization In Terms Of Daily Average Internet Usage Duration

\begin{tabular}{llccccc}
\hline & $\begin{array}{l}\text { Daily Average Internet } \\
\text { Usage Duration }\end{array}$ & $\mathrm{N}$ & $\begin{array}{c}\text { Rank } \\
\text { Average }\end{array}$ & $\mathrm{X}^{2}$ & $\mathrm{Sd}$ & $\mathrm{p}$ \\
\hline Cyberbully & $0-2$ hours & 13 & 13.46 & .923 & 2 & .630 \\
& $3-5$ hours & 11 & 12.50 & & & \\
6-8 hours & 1 & 12.50 & & & \\
& $0-2$ hours & 13 & 12.92 &, 120 & 2 & .942 \\
& 3-5 hours & 11 & 13.18 & & & \\
& $6-8$ hours & 1 & 12.00 & & & \\
\hline
\end{tabular}


According to Table 15, the cyberbullying status of the administrators does not differ statistically significantly in terms of daily average internet usage duration. $\left(X^{2}=0.923\right.$; $\left.s d=2 ; p>0.05\right)$. As a result of examining the cyber victimization of administrators in terms of daily average internet usage duration, there was no statistically significant difference $\left(\mathrm{X}^{2}=0.120 ; \mathrm{sd}=2 ; \mathrm{p}>0.05\right)$.

The Mann Whitney U test results regarding whether administrators' cyberbullying and victimization differ significantly in terms of having heard of the concept of cyberbullying are given in Table 16.

Table 16. Mann Whitney U Test Results of Administrators' Cyberbullying and Victimization Status in terms of Cyberbullying Awareness

\begin{tabular}{llcccccc}
\hline & $\begin{array}{l}\text { The awareness of } \\
\text { cyberbullying }\end{array}$ & $\mathrm{N}$ & Rank Sum & Rank Average & $\mathrm{U}$ & $\mathrm{Z}$ & $\mathrm{p}$ \\
\hline \multirow{2}{*}{ Cyberbully } & Yes & 24 & 312.50 & 13.02 & 11.500 & -.204 & .838 \\
& No & 1 & 12.50 & 12.50 & & & \\
& Yes & 24 & 313.00 & 13.04 & 11.000 & -.295 & .768 \\
& No & 1 & 12.00 & 12.00 & & & \\
\hline
\end{tabular}

In the study conducted with 25 administrators, administrators were asked whether they had heard of the concept of cyberbullying. According to the answers, the majority of the administrators (96\%) stated that they had heard of this concept, only 1 administrator had not.

When Table 16 is examined, it can be seen that being a cyberbully does not differ statistically significantly in terms of having heard of the concept $(U=11.5 ; \mathrm{p}>0.05)$. When administrators' scores of being cyber victims are examined, it is seen that these scores do not differ statistically significantly in terms of hearing the concept of cyberbullying $(\mathrm{U}=11 ; \mathrm{p}>0.05)$.

Teachers who heard the concept of cyberbullying were asked where they heard about this concept from. The values of the answers given to the related question are given in Table 17.

Table 17. Values of the Sources Where Teachers Heard the Concept of Cyberbullying

\begin{tabular}{lcc}
\hline & Frequency & Percentage \\
\hline From social media & 33 & 58.9 \\
From discussion programs/news on TV & 26 & 46.4 \\
From my colleagues & 14 & 25.0 \\
From printed publications (Newspapers, magazines, etc.) & 13 & 23.2 \\
From the personal website of an expert on the subject & 4 & 7.1 \\
From my administrators & 4 & 7.1 \\
From Parents & - & - \\
From a friend/relative/neighbor & - & - \\
From a training/seminar speaker I attended & - & - \\
\hline
\end{tabular}


According to Table 17, teachers mostly pointed to social media as the source from which the concept of cyberbullying was heard (58.9\%). It is followed by discussion programs/news on TV (46.4\%), my colleagues $(25 \%)$ and printed publication (newspapers, magazines, etc.) $(23.2 \%)$. It can be seen that the less preferred sources are the personal website of an expert (7.1\%) and administrators (7.1\%).

Teachers were given some behavioral examples and were asked which of them they would define as cyberbullying behavior. The findings obtained are given in Table 18.

Table 18. The Values of the Answers of the Teachers on Whether It Is Cyber Bullying in the Given Behavior Examples or Not

\begin{tabular}{|c|c|c|c|c|}
\hline & \multicolumn{2}{|c|}{ Yes } & \multicolumn{2}{|c|}{ No } \\
\hline & $f$ & $\%$ & $f$ & $\%$ \\
\hline $\begin{array}{l}\text { Sharing someone's personal information, photos and videos on the internet } \\
\text { without their permission or knowledge. }\end{array}$ & 53 & 94.6 & 3 & 5.4 \\
\hline Opening a fake account on behalf of someone else and impersonating them. & 52 & 92.9 & 4 & 7.1 \\
\hline Preparing defamatory and derogatory web pages about a person. & 51 & 91.1 & 5 & 8.9 \\
\hline Harassing someone using methods such as message attacks and spam. & 51 & 91.1 & 5 & 8.9 \\
\hline $\begin{array}{l}\text { Attacking a person's personal rights, special situations such as ethnic origin, etc., } \\
\text { in verbal, written or video content. }\end{array}$ & 51 & 91.1 & 5 & 8.9 \\
\hline $\begin{array}{l}\text { Sending derogatory, mocking, angry, rude, sexually abusive or violent messages } \\
\text { to others in online environments such as social networks or chat rooms. }\end{array}$ & 50 & 89.3 & 6 & 10.7 \\
\hline $\begin{array}{l}\text { Spreading rumors about someone or sharing matters related to their private life } \\
\text { with everyone on social networks. }\end{array}$ & 50 & 89.3 & 6 & 10.7 \\
\hline $\begin{array}{l}\text { Following all accounts of individuals on social networks in a way to disturb them } \\
\text { and constantly making negative comments on their posts. }\end{array}$ & 50 & 89.3 & 6 & 10.7 \\
\hline $\begin{array}{l}\text { Accessing personal files, folders and information on someone's computers with } \\
\text { harmful software such as viruses. }\end{array}$ & 50 & 89.3 & 6 & 10.7 \\
\hline Mocking or humiliating someone on the Internet by given them nicknames. & 49 & 87.5 & 7 & 12.5 \\
\hline $\begin{array}{l}\text { Organizing mutual friends and having them delete the target individual from their } \\
\text { friend list and block them, that is, socially exclude them. }\end{array}$ & 46 & 82.1 & 10 & 17.9 \\
\hline Talking or making noises in an annoying way by hiding the phone number. & 43 & 76.8 & 13 & 23.2 \\
\hline
\end{tabular}

According to the information in Table 18, all of the given behaviors were defined as cyberbullying by most of the participants. In addition, the first three behaviors that are considered as cyberbullying by the majority of teachers are as follows; "Sharing someone's personal information, photos and videos on the internet without their permission or knowledge $(\% 94,6)$; opening a fake account on behalf of someone else and impersonating them $(\% 92,9)$ and preparing defamatory and derogatory web pages about a person $(\% 91,1)$." The behavior that is considered as the least cyberbullying by the teachers is "Talking or making noises in an annoying way by hiding the phone number." with $76.8 \%$ score. 
In order to measure their awareness of cyberbullying, the teachers were asked some questions and asked to answer yes, no or undecided. The results obtained are presented in Table 19.

Table 19. Frequency Values of the Teacher Responses about Cyberbullying Awareness

\begin{tabular}{|c|c|c|c|c|c|c|}
\hline & \multicolumn{2}{|c|}{ Yes } & \multicolumn{2}{|c|}{ No } & \multicolumn{2}{|c|}{ Undecided } \\
\hline & $f$ & $\%$ & $f$ & $\%$ & $f$ & $\%$ \\
\hline $\begin{array}{l}\text { Would you like to receive training to learn about } \\
\text { cyberbullying, what kind of precautions to take against } \\
\text { cyberbullying and your legal rights? }\end{array}$ & 47 & 83.9 & 4 & 7.1 & 5 & 8.9 \\
\hline Is cyberbullying a crime determined and punishable by law? & 33 & 58.9 & 5 & 8.9 & 18 & 32.1 \\
\hline Can you realize if your child or a student is being cyberbullied? & 29 & 51.8 & 8 & 14.3 & 19 & 33.9 \\
\hline Can you realize if your child or a student is cyberbullying? & 22 & 39.3 & 11 & 19.6 & 23 & 41.1 \\
\hline $\begin{array}{l}\text { Do you know what to do when you, your child or a student are } \\
\text { faced with cyberbullying? }\end{array}$ & 21 & 37.5 & 17 & 30.4 & 18 & 32.1 \\
\hline $\begin{array}{l}\text { Do you know what your legal rights are when you, your child } \\
\text { or a student are exposed to cyberbullying? }\end{array}$ & 15 & 26.8 & 27 & 48.2 & 14 & 25.0 \\
\hline Have you ever thought that your child has been cyberbullied? & 4 & 7.1 & 40 & 71.4 & 12 & 21.4 \\
\hline Have you ever thought that your child has cyberbullied? & 1 & 1.8 & 37 & 66.1 & 18 & 32.1 \\
\hline
\end{tabular}

According to Table 19, 83.92\% of the participants answered yes to "Would you like to receive training to learn about cyberbullying, what kind of precautions to take against cyberbullying and your legal rights?". Similarly, more than half of the participants answered yes to the following questions: "Is cyberbullying a crime determined and punishable by law? (58.9\%)"; "Can you realize if your child or a student is being cyberbullied? (51.8\%)", the question that the teachers were most indecisive about was "Can you realize if your child or a student is cyberbullying?" with $41.1 \%$.

Administrators who heard the concept of cyberbullying were asked where they heard about this concept from. The values of the answers given to the related question are given in Table 20.

Table 20. Values of the Sources Where Administrators Heard the Concept of Cyberbullying

\begin{tabular}{lcc}
\hline & Frequency & Percentage \\
\hline From social media & 14 & 56.0 \\
From discussion programs/news on TV & 9 & 36.0 \\
From printed publications (Newspapers, magazines, etc.) & 9 & 36.0 \\
From a training/seminar speaker I attended & 8 & 32.0 \\
From my colleagues & 7 & 28.0 \\
From teachers working in my institution & 5 & 20.0 \\
From the personal website of an expert on the subject & 2 & 8.0 \\
From Parents & 1 & 4.0 \\
From a friend/relative/neighbor & 1 & 4.0 \\
\hline
\end{tabular}


According to Table 20, administrators mostly pointed to social media as the source from which the concept of cyberbullying was heard (56\%). It is followed by discussion programs/news on TV (36\%), printed publication such as newspapers, magazines (36\%), and a training/seminar speaker I attended (32\%). It can be seen that the less preferred sources are the personal website of an expert (8\%), parents $(4 \%)$, and friend/relative/neighbor $(4 \%)$.

Administrators were given some behavioral examples and were asked which of them they would define as cyberbullying behavior. The findings obtained are given in Table 21.

Table 21. The Values of the Answers of the Administrators on whether it is Cyber Bullying in the Given Behavior Examples or Not

\begin{tabular}{|c|c|c|c|c|}
\hline & \multicolumn{2}{|c|}{ Yes } & \multicolumn{2}{|c|}{ No } \\
\hline & $f$ & $\%$ & $f$ & $\%$ \\
\hline $\begin{array}{l}\text { Sending derogatory, mocking, angry, rude, sexually abusive or violent messages } \\
\text { to others in online environments such as social networks or chat rooms. }\end{array}$ & 25 & 100.0 & - & - \\
\hline $\begin{array}{l}\text { Spreading rumors about someone or sharing matters related to their private life } \\
\text { with everyone on social networks. }\end{array}$ & 25 & 100.0 & - & - \\
\hline Preparing defamatory and derogatory web pages about a person. & 25 & 100.0 & - & - \\
\hline Opening a fake account on behalf of someone else and impersonating them. & 25 & 100.0 & - & - \\
\hline $\begin{array}{l}\text { Following all accounts of individuals on social networks in a way to disturb them } \\
\text { and constantly making negative comments on their posts. }\end{array}$ & 25 & 100.0 & - & - \\
\hline Harassing someone using methods such as message attacks and spam. & 25 & 100.0 & - & - \\
\hline $\begin{array}{l}\text { Attacking a person's personal rights, special situations such as ethnic origin, etc., } \\
\text { in verbal, written or video content. }\end{array}$ & 25 & 100.0 & - & - \\
\hline $\begin{array}{l}\text { Sharing someone's personal information, photos and videos on the internet } \\
\text { without their permission or knowledge. }\end{array}$ & 24 & 96.0 & 1 & 4.0 \\
\hline $\begin{array}{l}\text { Accessing personal files, folders and information on someone's computers with } \\
\text { harmful software such as viruses. }\end{array}$ & 23 & 92.0 & 2 & 8.0 \\
\hline Mocking or humiliating someone on the Internet by given them nicknames. & 23 & 92.0 & 2 & 8.0 \\
\hline $\begin{array}{l}\text { Organizing mutual friends and having them delete the target individual from their } \\
\text { friend list and block them, that is, socially exclude them. }\end{array}$ & 22 & 88.0 & 3 & 12.0 \\
\hline Talking or making noises in an annoying way by hiding the phone number. & 22 & 88.0 & 3 & 12.0 \\
\hline
\end{tabular}

According to the information in Table 21, all of the given behaviors were defined as cyberbullying by most of the administrators. The first three behaviors that are considered as cyberbullying by all administrators are as follows: "Sending derogatory, mocking, angry, rude, sexually abusive or violent messages to others in online environments such as social networks or chat rooms." "Spreading rumors about someone or sharing matters related to their private life with everyone on social networks." "Preparing defamatory and derogatory web pages about a person." The behavior that is considered as cyberbullying by fewer administrators is "Talking or making noises in an annoying way by hiding the phone number." with $88 \%$ score. 
In order to measure their awareness of cyberbullying, the administrators were asked some questions and asked to answer yes, no or undecided. The results obtained are presented in Table 22.

Table 22. The Values of the Answers of the Administrators to the Questions Asked to Measure Cyberbullying Awareness

\begin{tabular}{|c|c|c|c|c|c|c|}
\hline & \multicolumn{2}{|c|}{ Yes } & \multicolumn{2}{|c|}{ No } & \multicolumn{2}{|c|}{ Undecided } \\
\hline & $f$ & $\%$ & $f$ & $\%$ & $f$ & $\%$ \\
\hline Would you like to get training to learn more about cyberbullying? & 19 & 76.0 & 3 & 12.0 & 3 & 12.0 \\
\hline $\begin{array}{l}\text { Do you think that parents who have children in your institution } \\
\text { need cyberbullying information training? }\end{array}$ & 19 & 76.0 & 2 & 8.0 & 4 & 16.0 \\
\hline Is cyberbullying a crime determined and punishable by law? & 17 & 68.0 & 1 & 4.0 & 7 & 28.0 \\
\hline $\begin{array}{l}\text { Do you think that teachers working in your institution need } \\
\text { cyberbullying information training? }\end{array}$ & 17 & 68.0 & 3 & 12.0 & 5 & 20.0 \\
\hline $\begin{array}{l}\text { Do you know what to do when you, your child or a student are } \\
\text { faced with cyberbullying? }\end{array}$ & 16 & 64.0 & 4 & 16.0 & 5 & 20.0 \\
\hline Can you realise if your child or a student is being cyberbullied? & 11 & 44.0 & 6 & 24.0 & 8 & 32.0 \\
\hline Can you realise if your child or a student is cyberbullying? & 10 & 40.0 & 8 & 32.0 & 7 & 28.0 \\
\hline $\begin{array}{l}\text { Do you know what your legal rights are when you, your child or a } \\
\text { student are exposed to cyberbullying? }\end{array}$ & 10 & 40.0 & 9 & 36.0 & 6 & 24.0 \\
\hline Have you ever thought that your child has been cyberbullied? & 2 & 8.0 & 21 & 84.0 & 2 & 8.0 \\
\hline Have you ever thought that your child has cyberbullied? & - & - & 23 & 92.0 & 2 & 8.0 \\
\hline
\end{tabular}

According to Table $22,76 \%$ of the administrators answered yes to the following questions "Would you like to get training to learn more about cyberbullying?" and "Do you think that parents who have children in your institution need cyberbullying information training?" Similarly, more than half of the participants answered yes to the following questions: "Is cyberbullying a crime determined and punishable by law? (68\%)" "Do you think that teachers working in your institution need cyberbullying information training? (\%68)", "Do you know what to do when you, your child or a student are faced with cyberbullying? (\%64)". The most undecided question of the administrators is "Can you realise if your child or a student is being cyberbullied?" with $32 \%$ score.

Teachers were asked to choose from the given list the precaution(s) they took to avoid cyberbullying and to protect themselves, their children and students from cyberbullying. The obtained results are given in Table 23.

Table 23. Values of Answers to the Question Asked to Determine Teachers' Methods of Combating Cyberbullying

\begin{tabular}{|c|c|c|c|c|}
\hline & \multicolumn{2}{|c|}{ Yes } & \multicolumn{2}{|c|}{ No } \\
\hline & $f$ & $\%$ & $f$ & $\%$ \\
\hline $\begin{array}{l}\text { Talking to my child and students about the advantages and disadvantages of } \\
\text { the internet and information technologies. }\end{array}$ & 54 & 96.4 & 2 & 3.6 \\
\hline Not accepting friendship requests from people I don't know on social media. & 54 & 96.4 & 2 & 3.6 \\
\hline
\end{tabular}




\begin{tabular}{|c|c|c|c|c|}
\hline & \multicolumn{2}{|c|}{ Yes } & \multicolumn{2}{|c|}{ No } \\
\hline & $f$ & $\%$ & $f$ & $\%$ \\
\hline Not adding people I don't know as friends on social media. & 53 & 94.6 & 3 & 5.4 \\
\hline Not sharing my username and password with anyone. & 52 & 92.9 & 4 & 7.1 \\
\hline Using the shared computer in school for business purposes only. & 52 & 92.9 & 4 & 7.1 \\
\hline $\begin{array}{l}\text { Limiting/controlling my child's or students' usage time of internet-connected } \\
\text { device. }\end{array}$ & 52 & 92.9 & 4 & 7.1 \\
\hline Setting the login password on the devices we connect to the Internet. & 51 & 91.1 & 5 & 8.9 \\
\hline $\begin{array}{l}\text { Logging out from the sites and platforms logged in with a password with the } \\
\text { secure log in button. }\end{array}$ & 51 & 91.1 & 5 & 8.9 \\
\hline To know the security settings and policies of the websites I use for shopping. & 51 & 91.1 & 5 & 8.9 \\
\hline $\begin{array}{l}\text { Being in communication with parents constantly, taking into account their } \\
\text { observations and warnings about their children. }\end{array}$ & 51 & 91.1 & 5 & 8.9 \\
\hline $\begin{array}{l}\text { Setting and implementing texting and sharing rules on virtual platforms that I } \\
\text { use to communicate with parents. }\end{array}$ & 51 & 91.1 & 5 & 8.9 \\
\hline $\begin{array}{l}\text { Observing if there are any unusual differences in the behavior of my child or } \\
\text { students. }\end{array}$ & 51 & 91.1 & 5 & 8.9 \\
\hline Supervising my child or students when using an internet-connected device. & 50 & 89.3 & 6 & 10.7 \\
\hline $\begin{array}{l}\text { Not adding anyone, even someone I know, as a friend on social media } \\
\text { without asking permission. }\end{array}$ & 50 & 89.3 & 6 & 9.7 \\
\hline $\begin{array}{l}\text { Not sharing my personal computer /smart phone / tablet computer with } \\
\text { others. }\end{array}$ & 49 & 87.5 & 7 & 12.5 \\
\hline $\begin{array}{l}\text { Not sharing my personal information (ID number, mobile number, address, } \\
\text { password information, etc.) with anyone on the internet. }\end{array}$ & 49 & 87.5 & 7 & 12.5 \\
\hline Adjusting privacy and security settings in my social network accounts. & 48 & 85.7 & 8 & 14.3 \\
\hline Setting the screen password on the devices we connect to the Internet. & 47 & 83.9 & 9 & 16.1 \\
\hline $\begin{array}{l}\text { Not accessing websites that require a password on the internet with devices } \\
\text { belonging to colleagues/friends/neighbors/relatives. }\end{array}$ & 47 & 83.9 & 9 & 16.1 \\
\hline $\begin{array}{l}\text { Having information about the privacy and security policies of social } \\
\text { networking companies. }\end{array}$ & 47 & 83.9 & 9 & 16.1 \\
\hline Not saving my username and password information anywhere. & 44 & 78.6 & 12 & 21.4 \\
\hline Not opening e-mails from people/institutions I don't know. & 44 & 78.6 & 12 & 21.4 \\
\hline Using licensed antivirus on devices we connect to the Internet. & 43 & 76.8 & 13 & 23.2 \\
\hline $\begin{array}{l}\text { Using two-step verification for the sites we } \log \text { in with a username and } \\
\text { password. }\end{array}$ & 42 & 75.0 & 14 & 25 \\
\hline $\begin{array}{l}\text { Answering no to the question of "remember the password for the next } \\
\text { logins" on sites entered with a password. }\end{array}$ & 42 & 75.0 & 14 & 25.0 \\
\hline Regularly updating my social network accounts. & 42 & 75.0 & 14 & 25.0 \\
\hline Reading terms of use when downloading smart phone apps. & 42 & 75.0 & 14 & 25.0 \\
\hline Using security filter on devices we connect to the Internet. & 41 & 73.2 & 15 & 26.8 \\
\hline
\end{tabular}




\begin{tabular}{|c|c|c|c|c|}
\hline & \multicolumn{2}{|c|}{ Yes } & \multicolumn{2}{|c|}{ No } \\
\hline & $f$ & $\%$ & $f$ & $\%$ \\
\hline Not using public internet connections that do not require a password. & 41 & 73.2 & 15 & 26.8 \\
\hline Adjusting Google Play parental control settings. & 41 & 73.2 & 15 & 26.8 \\
\hline Adjusting e-mail security settings. & 41 & 73.2 & 15 & 26.8 \\
\hline Following the updates and news about cyberbullying. & 41 & 73.2 & 15 & 26.8 \\
\hline $\begin{array}{l}\text { Regularly updating the operating systems installed on the devices we connect } \\
\text { to the Internet. }\end{array}$ & 39 & 69.6 & 17 & 30.4 \\
\hline $\begin{array}{l}\text { Periodically changing the passwords for the sites that we log in with a user } \\
\text { name and password. }\end{array}$ & 38 & 67.9 & 18 & 32.1 \\
\hline Scanning attachments in emails for viruses before opening them. & 38 & 67.9 & 18 & 32.1 \\
\hline Not sharing my location information on social media. & 38 & 67.9 & 18 & 32.1 \\
\hline $\begin{array}{l}\text { Setting different passwords for devices, platforms and accounts that require a } \\
\text { login password. }\end{array}$ & 36 & 64.3 & 20 & 35.7 \\
\hline $\begin{array}{l}\text { Turning off/taping the cameras of the devices we use to connect to the } \\
\text { internet when we are not using them. }\end{array}$ & 30 & 53.6 & 26 & 46.4 \\
\hline Handwriting and spelling Internet addresses. & 28 & 50.0 & 28 & 50.0 \\
\hline
\end{tabular}

When Table 23 is examined, it can be seen that all of the given measures are implemented by more than half of the participants. The five most preferred measures are; Talking to my child and students about the advantages and disadvantages of the internet and information technologies (96.4\%), Not accepting friendship requests from people I don't know on social media (96.4\%), Not adding people I don't know as friends on social media (94.6\%), Not sharing my username and password with anyone (92.9\%) and Using the shared computer in school for business purposes only (92.9\%). The least preferred measures by teachers are turning off / taping the cameras of the devices we use to connect to the internet when we are not using them with $53.6 \%$ and handwriting and spelling Internet addresses with 50\%.

Administrators were asked to choose from the given list the precaution(s) they took to avoid cyberbullying and to protect themselves, their children and students from cyberbullying. The results obtained are given in Table 24.

Table 24. Values of Answers to the Question Asked to Determine Administrators' Methods of Combating Cyberbullying

\begin{tabular}{|c|c|c|c|c|}
\hline & \multicolumn{2}{|c|}{ Yes } & \multicolumn{2}{|c|}{ No } \\
\hline & $f$ & $\%$ & $f$ & $\%$ \\
\hline $\begin{array}{l}\text { Not sharing my personal information (ID number, mobile number, address, } \\
\text { password information, etc.) with anyone on the internet. }\end{array}$ & 24 & 96.0 & 1 & 4.0 \\
\hline $\begin{array}{l}\text { Setting and implementing texting and sharing rules on virtual platforms that I } \\
\text { use to communicate with parents. }\end{array}$ & 24 & 96.0 & 1 & 4.0 \\
\hline Warning and informing teachers working in my institution about not to share & 24 & 96.0 & 1 & 4.0 \\
\hline
\end{tabular}




\begin{tabular}{lllll}
\hline & Yes & \multicolumn{2}{c}{ No } \\
\hline & $f$ & $\%$ & $f$ & $\%$ \\
\hline
\end{tabular}

student images on their personal social media accounts without the permission

of the parents.

Not adding anyone, even someone I know, as a friend on social media without $\begin{array}{rllll}24 & 96.0 & 1 & 4.0\end{array}$ asking permission.

Not adding people I don't know as friends on social media.

Not accepting friendship requests from people I don't know on social media.

Not sharing my username and password with anyone.

Not sharing my personal computer/smart phone / tablet computer with others.

Adjusting privacy and security settings in my social network accounts.

Not sharing student's images in the social network pages of our school without the permission of the parents.

Not sharing my location information on social media.

Logging out from the sites and platforms logged in with a password with the secure log in button.

Using the computer in my office room for business purposes only.

Adjusting e-mail security settings.

Observing if there are any unusual differences in my child's behavior.

Making the internet connection in our school available in such a way that it is logged in with a password.

Having information about the privacy and security policies of social networks.

Talking to my child about the advantages and disadvantages of the internet and information technologies.

Following the updates and news about cyberbullying.

$\begin{array}{llll}24 & 96.0 & 1 & 4.0\end{array}$

$\begin{array}{llll}24 & 96.0 & 1 & 4.0\end{array}$

$\begin{array}{llll}23 & 92.0 & 2 & 8.0\end{array}$

$\begin{array}{llll}23 & 92.0 & 2 & 8.0\end{array}$

$\begin{array}{llll}23 & 92.0 & 2 & 8.0\end{array}$

$\begin{array}{llll}23 & 92.0 & 2 & 8.0\end{array}$

Using two-step verification for the sites we log in with a username and password.

Not opening e-mails from people/institutions I don't know.

To know the security settings and policies of the websites I use for shopping.

Not saving my username and password information anywhere.

Not accessing websites that require a password on the internet with devices belonging to colleagues/friends/neighbors/relatives.

Not using public internet connections that do not require a password.

$\begin{array}{llll}22 & 88.0 & 3 & 12.0\end{array}$

$\begin{array}{llll}22 & 88.0 & 3 & 12.0\end{array}$

$\begin{array}{llll}22 & 88.0 & 3 & 12.0\end{array}$

$\begin{array}{llll}22 & 88.0 & 3 & 12.0\end{array}$

Regularly updating my social network accounts.

Scanning attachments in emails for viruses before opening them.

$\begin{array}{llll}21 & 84.0 & 4 & 16.0\end{array}$

$\begin{array}{llll}21 & 84.0 & 4 & 16.0\end{array}$

Setting the login password on the devices we connect to the Internet.

$\begin{array}{llll}21 & 84.0 & 4 & 16.0\end{array}$

$\begin{array}{llll}20 & 80.0 & 5 & 20.0\end{array}$

Using licensed antivirus on devices we connect to the Internet.

$\begin{array}{llll}20 & 80.0 & 5 & 20.0\end{array}$

$\begin{array}{llll}20 & 80.0 & 5 & 20.0\end{array}$

$\begin{array}{llll}19 & 76.0 & 6 & 24.0\end{array}$

$\begin{array}{llll}19 & 76.0 & 6 & 24.0\end{array}$

$\begin{array}{llllll}\text { Answering no to the question of "remember the password for the next logins" } & 18 & 72.0 & 7 & 28.0\end{array}$ on sites entered with a password.

$\begin{array}{llllll}\text { Setting and implementing texting and sharing rules on virtual platforms that I } & 18 & 72.0 & 7 & 28.0\end{array}$ 


\begin{tabular}{|c|c|c|c|c|}
\hline & \multicolumn{2}{|c|}{ Yes } & \multicolumn{2}{|c|}{ No } \\
\hline & $f$ & $\%$ & $f$ & $\%$ \\
\hline use to communicate with teachers. & & & & \\
\hline Using security filter on devices we connect to the Internet. & 17 & 68.0 & 8 & 32.0 \\
\hline $\begin{array}{l}\text { Periodically changing the passwords for the sites that we log in with a user } \\
\text { name and password. }\end{array}$ & 17 & 68.0 & 8 & 32.0 \\
\hline Limiting/controlling my child's usage time of internet-connected device. & 17 & 68.0 & 8 & 32.0 \\
\hline $\begin{array}{l}\text { Regularly updating the operating systems installed on the devices we connect } \\
\text { to the Internet. }\end{array}$ & 16 & 64.0 & 9 & 36.0 \\
\hline $\begin{array}{l}\text { Setting different passwords for devices, platforms and accounts that require a } \\
\text { login password. }\end{array}$ & 16 & 64.0 & 9 & 36.0 \\
\hline Reading terms of use when downloading smart phone apps. & 16 & 64.0 & 9 & 36.0 \\
\hline Setting the screen password on the devices we connect to the Internet. & 15 & 60.0 & 10 & 40.0 \\
\hline Supervising my child when using an internet-connected device. & 15 & 60.0 & 10 & 40.0 \\
\hline $\begin{array}{l}\text { Turning off/taping the cameras of the devices we use to connect to the internet } \\
\text { when we are not using them. }\end{array}$ & 14 & 56.0 & 11 & 44.0 \\
\hline Adjusting Google Play parental control settings. & 13 & 52.0 & 12 & 48.0 \\
\hline Handwriting and spelling Internet addresses. & 9 & 36.0 & 16 & 64.0 \\
\hline
\end{tabular}

When Table 24 is examined, it can be seen that most of the given measures are implemented by more than half of the participants. The five most preferred measures are; "Not sharing my personal information (ID number, mobile number, address, password information, etc.) with anyone on the internet (96\%)", "Setting and implementing texting and sharing rules on virtual platforms that I use to communicate with parents (96\%)", "Warning and informing teachers working in my institution about not to share student images on their personal social media accounts without the permission of the parents (96\%)", "Not adding anyone, even someone I know, as friend on social media without asking permission. (96\%)", "Not adding people I don't know as friends on social media $(96 \%) "$. The least preferred measure by the administrators is handwriting and spelling Internet addresses with $36 \%$.

Interviews were held with volunteers among the teachers and administrators participating in the research. The purpose of the interviews is to express their views and suggestions on cyberbullying awareness and combating cyberbullying in the triangle of parents-teacher-administrator, apart from the questionnaire and scale questions. 25 teachers and 13 administrators voluntarily participated in the interview.

\section{Findings of Interview Questions with Teachers}

a. Have you ever witnessed someone around you, a family member, one of your students or your child being cyberbullied? If you witnessed, what kind of events were they? What was your attitude towards these events?

12 of the interviewed teachers stated that they had never witnessed a person around them, a family member, a 
student or their child being cyberbullied. 9 teachers stated that the passwords of their social media accounts were phished, 3 teachers stated that their financial information was stolen, and 1 teacher stated that there were bullying scenes in the game played by their children and banned the game.

\section{b. Do you think parents have enough knowledge about cyberbullying? What makes you think that?}

16 of the teachers answered no to this question. In general, they stated that they came to this conclusion from the fact that the amount of time children spend on the Internet is excessive and the parents' posts about their children on their social media accounts. Only 5 of the teachers stated that parents were sensitive about this issue, and they also stated that they came to this conclusion due to the high level of general education of the parents. 4 teachers did not answer this question.

c. Do you think your administrators have enough knowledge about cyberbullying? What makes you think that?

4 teachers answered yes to this question. In general, they stated that they reached to this opinion from their private communication. 12 teachers stated that the administrators had some knowledge but it was not enough, and that they had difficulty in keeping up with the rapid progress of technology. 4 teachers indicated that the knowledge level of the administrators was better than the knowledge level of the parents. 5 teachers stated that their administrators do not have enough information on this subject, and they also stated that their administrators are personally cyberbullies, especially in Whatsapp groups.

\section{d. What do you think should be done to combat cyberbullying, especially by or against children? (As the state, teachers, administrators, and parents)}

The most common answer to this question was "seminars should be held". 13 of the teachers stated that information about cyberbullying can be provided and awareness can be created through seminars. 5 teachers stated that parenting education and raising parents' awareness are the most important issues in this regard, and 5 teachers stated that to combat cyberbullying internet restrictions are necessary. 1 teacher stated that the advisory teachers should be given an opportunity in this regard and 1 teacher stated that cyberbullying should be taught to students at all levels as course content.

\section{Findings of Interview Questions with Administrators}

a. Have you ever witnessed someone around you, a family member, one of your students or your child being cyberbullied? If you witnessed, what kind of events were they? What was your attitude towards these events?

8 of the interviewed administrators answered to this question that they had never witnessed a person around them, a family member, one of their students or their children exposed to cyberbullying. 2 administrators stated that the passwords of their social media accounts were stolen, 2 administrators stated that they were cyberbullied by being called and disturbed on phone, and 1 administrator stated that their child was exposed to cyberbullying 
and they could solve the problem with a pedagogue.

\section{b. Do you think parents have enough knowledge about cyberbullying? What makes you think that?}

8 administrators answered no to this question. In general, it is stated that they came to this conclusion because of the wrong messages in parent Whatsapp groups, excessive time spent by children on the Internet in an uncontrolled way, and insufficient information. Only 5 of the administrators stated that the parents are aware of this issue and that they came to this conclusion because they closely follow the technology.

\section{c. Do you think your teachers have enough knowledge about cyberbullying? What makes you think that?}

5 administrators answered positively to this question. In general, they did not specify how they came to this conclusion. 6 administrators stated that teachers have some knowledge, but not enough, and that they have difficulty keeping up with the rapid progress of technology. 2 administrators stated that the knowledge level of the teachers is better than the knowledge level of the parents.

d. What do you think should be done to combat cyberbullying, especially by or against children? (As the state, teachers, administrators, and parents)

5 of the managers stated that information and awareness can be created about cyberbullying through seminars. 4 administrators stated that parenting education and parents' awareness are the most important issues in this regard, while 2 administrators stated that internet restrictions are necessary to combat cyberbullying. 1 administrator suggested that cyberbullying should be taught in schools as a subject.

\section{Discussion}

According to the findings, it is pleasing to say that the teachers and administrators participating in the research have lower levels of cyberbullying than their cyber victimization levels. According to another finding, the cyberbullying level of the teachers is higher than the cyberbullying level of the administrators. This difference may have been caused by factors such as the fact that the teachers participating in the research were younger compared to the administrators, and they spent more time on the Internet. Teachers' being cyberbully and cyber victim does not differ in terms of their gender. Although there are studies in the literature indicating that men are more cyberbullies compared to women (Horzum and Ayas, 2011; Li, 2007; Özer, 2016; Taştekin, 2016; Usta, 2013), it is noteworthy that these studies were mainly conducted with primary, secondary or high school students. In this study, data were collected from teachers, and the lack of difference among teachers can be attributed to their education level and high awareness of cyberbullying.

Cyberbullying status of teachers differs statistically significantly in terms of their age. It was concluded that the most fundamental difference is between teachers aged 18-28 and teachers aged 40-50, and younger teachers are more bullies. In the case of cyber victimization, it was detected that the most fundamental difference is again 
between the two groups of teachers and older teachers in the 40-50 age range are more victimized. It is noteworthy that the teachers with a higher cyberbullying score were born in the Y generation, and the teachers between the ages of 40-50 were born in the X generation (Kyles, 2005). Although X generation is the first generation to meet the computer (Topaktaş, 2021) and use the computer for business rather than entertainment purposes (Balat, 2019), Y generation is the first generation to meet the internet. Considering the meeting age with the internet and the purposes of using it, it is normal for teachers aged 18-28 to have a higher average cyberbullying score, and teachers aged between 40-50 years to have a higher average cyberbullied score.

The mean scores of cyberbullying and cyber-victims of teachers who do not have children were found to be higher than those who have children. Having children, especially digital native alpha generation (Prensky, 2001), requires having digital parenting competencies (Clark, 2011; Livingstone and Bulger, 2014). In addition, digital parents have to be role models for their children in technology and internet use. (Manap, 2020). For these reasons, it can be said that by acting more sensitively and responsibly about cyberbullying, teachers who have children do not bully. The noteworthy finding here is that the mean score of cyber victimization is high among teachers who have children. This finding shows that the strategies developed for personal protection against cyberbullies by teachers are not sufficient.

The cyberbullying status of teachers differs statistically significantly in terms of the daily average internet usage duration. It was found that the most fundamental difference is between teachers who use the internet for 0-2 hours on average and those who use the internet for 3-5 hours on average, in favor of those who use the internet for 3-5 hours. The research results of Dikmen and Tuncer (2017), Elmas (2016), Hinduja and Patchin (2008), Kocatürk (2014), Manap (2012), Özbay (2013), Serin (2012) support this finding.

Teachers who have not heard of the concept of cyberbullying are more bullies than those who have heard of it. According to this finding, it can be stated that the teachers participating in the study need to be informed more about cyberbullying. Almost all of the interviewed teachers stated that they wanted to receive training on cyberbullying. The fact that $38 \%$ of the interviewed administrators stated that teachers do not have enough knowledge about cyberbullying, and $46 \%$ of them stated that teachers have partial knowledge about cyberbullying and that training should be given, supports this finding.

Social media has the highest rate as the first channel that teachers and administrators hear about the concept of cyberbullying. The use of social media in Turkey is constantly increasing as it is in the world. According to January 2021 analysis, the number of social media users in Turkey increased by $13.2 \%$ compared to the same month of the previous year and reached 600 million. In addition, users in Turkey spend averagely 2 hours and 57 minutes a day on social media (Kemp, 2021). According to these figures, it can be considered as normal that teachers are mostly familiar with the concept of cyberbullying through social media.

Most of the teachers correctly marked all of the cyberbullying behaviors offered as options. In other words, teachers are aware of which behaviors are within the scope of cyberbullying. The fact is that teachers' cyberbullying mean scores are lower than cyber victim mean scores, that more than half of the teachers state that 
they can detect cyberbullying when their child or a student is being bullied, and that they know that cyberbullying is a crime also supports this finding.

The first strategy mostly preferred by teachers in combating cyberbullying is to talk to their children and students about the advantages and disadvantages of internet and information technologies. The fact that more than half of the teachers have children at preschool and primary school level, facilitates the implementation of giving information by communication. In many studies, similarly, it is pointed out that talking to children is an important tool in conscious use of technology and internet and in guiding children (Andrews, 2018; Broussard, 2021; Froeschle, Mayorga, Castillo, \& Hargrave, 2008; Gallo, 2021; Martín-Criado, Casas and Ortega-Ruiz, 2021; Mehari, Moore, Waasdorp, Varney, Berg, \& Leff, 2018; Nappa, Palladino, Nocentini, \& Menesini, 2021).

When teachers are asked to choose from the given list the precaution(s) they take to avoid cyberbullying incidents and protect both themselves and their children from these incidents, it was determined that most of the given precautions were implemented by more than half of the teachers. The fact that teachers' cyber victimization score means are generally low supports this finding. Regarding the parents; more than half of the teachers who participated in the interview stated that the parents do not have enough information about cyberbullying. They also added that the time children spend on the Internet and the posts of their children on the parents' social media accounts are effective in terms of reaching this conclusion.

Regarding the administrators; only 4 of the 26 teachers who participated in the interview stated that their administrator had sufficient knowledge about cyberbullying. 5 teachers stated that their administrator cyberbullied them through Whatsapp. The cyberbullying and cyber victimization means of the administrators are generally low, and the average cyberbullying score is also lower than the average cyber victimization score. The fact that more than half of the teachers participating in the research did not participate in the interview makes it difficult to generalize about administrators.

Age, gender, having children and the average daily internet usage duration do not cause a significant difference in the cyberbullying and cyber victimization status of administrators. Most of the administrators correctly marked all of the cyberbullying behaviors offered as options. In addition, more than half of the administrators stated that they know cyberbullying is a crime and what to do when they, their child or a student face cyberbullying. Based on these findings, it can be said that administrators know which behaviors are cyberbullying, in other words, they have awareness of cyberbullying.

When administrators are asked to choose from the given list the precaution(s) they take to avoid cyberbullying incidents and protect both themselves and their children from these incidents, it was determined that most of the given precautions were implemented by more than half of the administrators. The fact that the administrators participating in the research generally have low cyber victimization scores and that cyber victimization mean scores are higher than cyberbullying mean scores support this finding. The first strategy most preferred by administrators to combat cyberbullying is not to share their personal information with anyone on the internet. It is seen that administrators implement strategies for their children at a lower rate compared to teachers (For 
example, talking to the child $84 \%$ ). This situation may have been caused by the fact that more than half of the administrators have children at least at secondary school level, that the controls over the children became more difficult.

Among administrators who were asked for their opinions on combating cyberbullying, 5 of them requested seminars, while 4 of them emphasized the importance of raising awareness of parents. Organizing seminar was the most recommended issue by the teachers and administrators who participated in the interviews within the scope of combating cyberbullying. At this point, expectations from administrators become a current issue. Because, a school administrator should be an organizational leader who motivates corporate sharers, supports corporate culture, develops a common group vision and qualified teaching programs, improves learning environments, is a model for high achievement, and organizes human resources most effectively as the person responsible for learning outcomes (Smith and Piele, 1997). Therefore, necessary planning and implementation should be provided considering the requested seminars by the administrators at all levels.

\section{Conclusion}

Long interruption of education in the pandemic and unprepared transition of education sharers to distance education caused children to be in front of the screen even more. This situation, which sometimes occurs uncontrollably, causes children to face many risks and dangers, including cyberbullying. Therefore, responsibilities such as guiding, being a role model and supervising the time children spend in front of the screen, in other words, digital parenting competencies come to the fore. Being successful in dealing with risks such as cyberbullying and parents' ability to fulfill their digital parenting responsibilities, can be possible with the cooperation of educational institution administrators, teachers and parents. For this, as seen in the study's findings, it is important that all education sharers (administrator-teacher-parents) receive regular training on cyberbullying and other risks of internet. Besides, the continuation of studies on this subject will be an important part of the cooperation in order to reveal the needs and suggestions of education sharers.

In this context, the following can be recommended for future studies:

- Preschool teachers should be regularly trained in-service on cyberbullying and their awareness of cyberbullying should be increased.

- Preschool teachers should meet with parents and train them on how to protect their children against the harmful risks of the Internet.

- In order to raise awareness in children, lessons on how to use the Internet should be added to pre-school education programs.

- Administrators should be recommended to provide training on cyberbullying as a technology leader. By contacting the expert personnel working in the IT Crimes and Systems Branch Offices within the Provincial Directorate of Security, the school administrators can be ensured to give seminars on the appropriate use of information technologies for teachers, parents and students.

- The Ministry of National Education should organize special training programs for parents and provide training about internet use and cyberbullying. These trainings can be provided to parents by school 
counselling services. In this way, it can be ensured that parents become more controlling and conscious about their children's use of mobile phones and computers.

- Studies can be conducted to determine the perception levels of preschool children's parents and teachers about cyberbullying/cyber victimization.

- Studies can be conducted to measure the awareness levels of people (teacher, parent, school principal, other family members living in the same household, etc.) who may be involved to prevent cyberbullying.

\section{Note}

This article is produced from Halenur Akcay's master's thesis titled 'Investigation of Parents, Teachers and Managers of 36-72 Months-Old Preschool Children in Terms of Cyberbullying Awareness, Cyber Bully / Cyber Victim Status and Cyberbullying Fighting Strategies in Terms of Various Variables”.

\section{References}

Aksaray, S. (2011). Siber zorbalık. (Cyber bullying) Ç.Ü. Sosyal Bilimler Enstitüsü Dergisi, 20(2), 405-432.

Andrews, G. L. (2018). An exploration of parents communication needs and preferences when interacting with their childens school regarding cyberbullying issues. (Doctoral Dissertation). Doctor of Science in Information Systems and Communications, Robert Morris University, USA.

Balat, A. (14 Nisan, 2019). X, Y ve Z Kuşakları Nedir? (What are Generations X, Y and Z?) Retrieved from https://www. ahmetbalat.com/x-y-ve-z-kusaklari-nedir/

Broussard, L. (2021). Cyberbullying: a resource for parents of elementary school-aged

children. (Doctoral Dissertation). Pepperdine University, Graduate School of Education and Psychology, USA.

Büyüköztürk, Ş., Kılıç Çakmak, E., Akgün, Ö.E., Karadeniz, Ş., \& Demirel, F. (2008). Bilimsel araştırma yöntemleri (Scientific research methods) (14. Bask1). Ankara: Pegem Yayınları.

Clark, L. S. (2011). Parental mediation theory for the digital age. Communication Theory, 21 (2011), 323-343.

Dehue, F. (2013). Cyberbullying research: New perspectives and alternative methodologies. Introduction to the special issue. Journal of Community\&Applied Social Psychology, 23(1), 1-6. doi:10.1002/casp.2139

Dikmen, M., \& Tuncer, M. (2017). Akademisyenlerin siber zorbalığa yönelik algıları ve mücadele etme yöntemleri.( Perceptions of academics towards cyberbullying and their methods of dealing with it) Dicle Üniversitesi Ziya Gökalp Ĕgitim Fakültesi Dergisi, 31, 675-686.

Doane, A. N., Kelley, M. L., Chiang, E. S., \& Padilla, M. A. (2013). Development of the cyberbullying experiences survey. Emerging Adulthood, 1(3), 207-218. doi:10.1177/2167696813479584

Elmas, B. (2016). Öğretmen adaylarının siber zorbalık ve siber mağduriyet algı düzeylerinin incelenmesi. (Examining the cyber bullying and cyber victimization perception levels of teacher candidates). Yayınlanmamış Yüksek Lisans Tezi. Afyon Kocatepe Üniversitesi, Fen Bilimleri Enstitüsü, Afyon.

Froeschle, J. G., Mayorga, M., Castillo, Y., \& Hargrave, T. (2008). Strategies to prevent and heal the mental anguish caused by cyberbullying. Middle School Journal, 39:4, 30-35, DOI: $10.1080 / 00940771.2008 .11461642$ 
Gallo, J. (2021). Teacher and parent perceptions of cyberbullying in a middle school setting. (Doctoral Dissertation). Clinical Psychology, Walden University, USA.

Hamer, M., Stamatakis, E., \& Mistras, G. (2009). Psychological distress, television viewing and physical activity in children aged 4 to 12 year. Pediatrics, 123 (5), 1263-1268.

Higgins, S., Xiao, Z., \& Katsipataki, M. (2012). The impact of digital technology on learning: A summary for the education endowment foundation. Durham, UK: Education Endowment Foundation and Durham University.

Hinduja, S., \& Patchin, J. W. (2008). Cyberbullying: An exploratory analysis of factors related to offending and victimization. Deviant Behavior, 29(2), 129-156. doi:10.1080/01639620701457816

Horzum, M. B., \& Ayas, T. (2011). Ortaöğretim öğrencilerinin sanal zorba ve mağdur olma düzeylerinin okul türü ve cinsiyet açısından incelenmesi. (Examination of secondary school students' cyberbullying and victimization levels in terms of school type and gender.) Eğitim Bilimleri ve Uygulama, 10 (20), 139159.

Jöreskog, K. G., \& Sörbom, D. (1999). LISREL 8.30 and PRELIS 2.30. Chicago, IL: Scientific Software International.

Kemp, S. (2021). Digital 2021: Turkey. Retrieved from https:// datareportal.com/reports/digital-2021-turkey

Kocatürk, M. (2014). Ortaokul öğrencilerinde akran zorbalığı ile siber zorbalık arasındaki ilişkinin incelenmesi. (Examining the relationship between peer bullying and cyberbullying in secondary school students.) Yüksek lisans Tezi. İstanbul Üniversitesi, Eğitim Bilimleri Enstitüsü, İstanbul.

Kyles, D. (2005). Managing your multigenerational workforce. Strategic Finance, 87(6), 53-55.

Leech, N. L., \& Onwuegbuzie, A.J. (2007). A typology of mixed methods research designs. Qual Quant, 43, $265-275$.

Li, Q. (2007). New bottle but oldwine: A research of cyberbullying in schools. Computers in Human Behavior, 23(4), 1777-1791.

Livingstone, S., \& Bulger, M. E. (2013). A global agenda for children's rights in the digital age. Recommendations for developing UNICEF's research strategy. London: The London School of Economics and Political Science.

Livingstone, S., \& Haddon, L. (2009). EU Kids Online: Final report. Deliverable D6.5 for the EC Safer Internet Plus Programme. London: EU Kids Online, LSE. Retrieved from http://eprints.lse.ac.uk/24372/

Livingstone, S., Mascheroni, G., \& Staksrud, E. (2015). Developing a framework for researching children's online risks and opportunities in Europe. London: EU Kids Online. Retrieved from http://eprints.lse.ac.uk/64470/

Manap, A. (2012). İlköğretim ikinci kademe öğrencileri ve siber zorbalık: Samsun ili örneği. (Secondary school students and cyber bullying: The case of Samsun province.) Yüksek Lisans Tezi. Ondokuz Mayıs Üniversitesi, Eğitim Bilimleri Enstitüsü, Samsun.

Manap, A. (2020). Anne babalarda dijital ebeveynlik farkındalığının incelenmesi. (Examination of digital parenting awareness in parents.) Doktora Tezi. İnönü Üniversitesi, Eğitim Bilimleri Enstitüsü, Eğitim Bilimleri Ana Bilim Dalı, Rehberlik ve Psikolojik Danışmanlık Bilim Dalı, Malatya. 
Martín-Criado, J. M., Casas, J. A., \& Ortega-Ruiz, R. (2021). Parental supervision: predictive variables of positive involvement in cyberbullying prevention. International Journal Environment Research and Public Health, 18, 1562. Retrieved from https://doi.org/10.3390/ijerph

Mehari, K. R., Moore, W., Waasdorp, T. E., Varney, O., Berg, K., \& Leff, S. S. (2018). Cyberbullying prevention: Insight and recommendations from youths, parents, and paediatricians. Child Care Health and Development, 44, 616-622. Retrieved from https://doi.org/10.1111/cch.12569

Nappa, M. R., Palladino, B. E., Nocentini, A., \& Menesini, E. (2021). Do the face-to-face actions of adults have an online impact? The effects of parent and teacher responses on cyberbullying among students, European Journal of Developmental Psychology, 18:6, 798-813, DOI: 10.1080/17405629.2020.1860746

O’Keeffe, G. S., \& Clarke-Pearson, K. (2011). The impact of social media on children, adolescents and families. Pediatrics, 127(4), 800-804. doi:10.1542/peds.2011-0054.

Özbay, A. (2013). Ergenlerde siber zorbalık, siber mağduriyet, aleksitimi ve öfke ifade etme biçimleri arasındaki ilişki. (The relationship between cyberbullying, cyber victimization, alexithymia and anger expression styles in adolescents). Yayınlanmamış Yüksek Lisans Tezi. Fatih Üniversitesi, Sosyal Bilimler Enstitüsü, İstanbul.

Patchin J. W., \& Hinduja S. (2006). Bullies move beyond the schoolyard. Youth Violence Juv Justice. 2006, 4: 148-169.

Pew Research Center (2017). Retrieved from https://goo.gl/TzsrBN

Prensky, M. (2001). Digital natives, digital immigrants. On the Horizon, 9(5), 1-5.

Serin, H. (2012). Ergenlerde siber zorbalık / siber mağduriyet yaşantıları ve bu davranışlara ilişkin öğretmen ve eğitim yöneticilerinin görüşleri. (Cyberbullying / cyber victimization experiences in adolescents and the opinions of teachers and education administrators about these behaviors.). Doktora Tezi. İstanbul Üniversitesi Sosyal Bilimler Enstitüsü Eğitim Bilimleri Anabilim Dalı, İstanbul.

Smith, S. C., \& Piele, P. K. (1997). Introduction. school leadership handbook for excellenge (3rd Ed.) in (1-12). S. C. Smith, \& P. K. Piele (Eds). University of Oregon:ERIC

Taiwo, R. (2015). Cyberbehavior. M. Khosrow-Pour (Ed.), Encyclopedia of Information Science and Technology in (3. bs., 2972-2980). Hershey, PA: IGI Global. doi:10.4018/978-1-4666-5888- 2.ch290

Tanrikulu, İ., \& Erdur Baker, Ö. (2020). Psychometric properties of a cyberbullying inventory for university students. British Journal of Guidance \& Counselling, 1-14. DOI: 10.1080/03069885.2020.1775174

Taştekin, E. (2016). Ergenlerin arkadaşlık ilişkileri ve benlik saygısı ile siber zorbalık ve siber mağduriyet arasındaki ilişkiler. (Relationships between adolescents' friendships and self-esteem and cyberbullying and cyber victimization). Yüksek Lisans Tezi. Hacettepe Üniversitesi Sağlık Bilimleri Enstitüsü, Ankara.

Taylan H., Aydın F., \& Topal M. (2017). Ortaokul öğrencilerinin sanal zorba olma durumlarının çeşitli değişkenler açısından incelenmesi: Sakarya ili örneği. (Examining the cyberbullying status of secondary school students in terms of various variables: The case of Sakarya province). Çevrimiçi Journal of Technology Addiction \& Cyberbullying, 4(1), 1-59.

Topaktaş, S. (2021). Dijitalleşme sürecinde bilgi ve bilgiyi kullanma biçimleri: kuşaklar arası bir kıyaslama. (Information and ways of using information in the digitalization process: an intergenerational comparison). Yüksek Lisans tezi. Sosyoloji Anabilim Dalı, Karabük Üniversitesi. 
Usta, E. (2017). University students' views about their cyberbullying behaviors and self-exposition. Online Submission, 8(22), 67-71.

Uygarer, G. (2019). Çocuk ve ergenlerde siber zorbalıkla başa çıkmada gerçeklik terapisinin etkililiğinin incelenmesi. (Investigation of the effectiveness of reality therapy in coping with cyberbullying in children and adolescents). Türk Psikolojik Danışma ve Rehberlik Dergisi, 9(53), 297-315.

\section{Author Information}

\begin{tabular}{ll}
\hline Nilgun Tosun & Halenur Akcay \\
(iD https://orcid.org/0000-0002-3470-858X & (iD https:/orcid.org/0000-0002-2200-5289 \\
Trakya University & Trakya University \\
Faculty of Education, CEIT Department & Faculty of Education, CEIT Department \\
Edirne, Turkey & Edirne, Turkey \\
Contact e-mail: nilgunt@trakya.edu.tr & \\
\hline
\end{tabular}

